
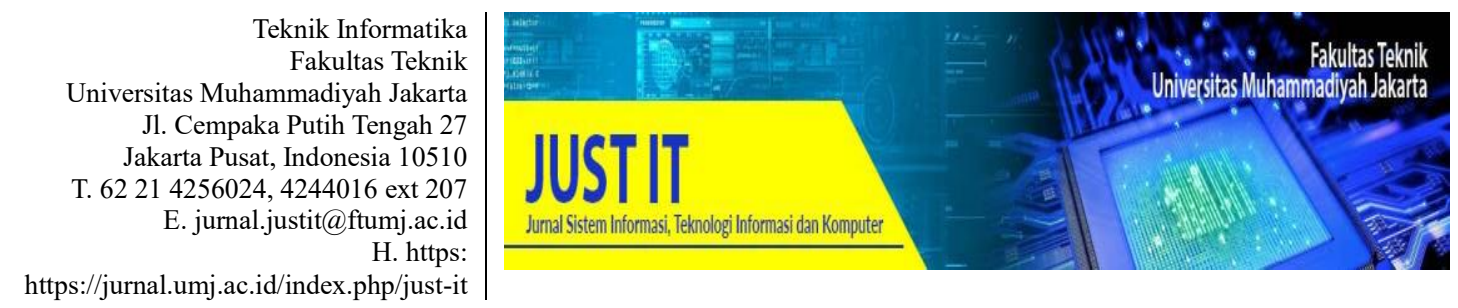

\title{
APLIKASI SISTEM INFORMASI INVENTARIS PERUSAHAAN UNTUK MENDUKUNG MANAJEMEN PROCUREMENT
}

\author{
Setia Bakti Christian ${ }^{1}$, Riri Fajriah ${ }^{2}$ \\ Jurusan Sistem Informasi, Fakultas Ilmu Komputer, Universitas Mercu Buana
}

41816110112@student.mercubuana.ac.id ${ }^{1}$,riri.fajriah@mercubuana.ac.id²

\begin{abstract}
Abstrak
Informasi yang cepat sangat dibutuhkan setiap perusahaan untuk membantu efektifitas kerja. Sudah menjadi suatu kebutuhan bagi perusahaan untuk menggunakan sistem yang dapat menghasilkan informasi yang cepat. Hal ini yang diperlukan oleh sebuah perusahaan untuk pengelolaan aset dan barang secara terstruktur agar dikemudian hari tidak terjadi sebuah kekeliruan dalam pencatatan barang terlebih lagi apabila masih dilakukan dengan mencatat pada kertas. Sehingga diperlukan cara untuk membuat sebuah aplikasi menggunakan metode waterfall, metode ini bertujuan untuk pengembangan sistem agar dapat dilakukan secara berurutan, maka untuk memperbaiki masalah ini diperlukan pendekatan lain dengan Soft System Metodelogy (SSM) untuk memecah permasalahan didalam perusahaan agar mendapatkan tujuan lain, hingga akhirnya menjadi referensi untuk mengembangkan dan meningkatkan layanan lainnya dengan menghubungkan manajemen pengadaan barang. Dengan adanya sistem informasi inventaris yang terintegrasi dengan procurement yang berbasis website ini memudahkan general affair untuk melakukan pencatatan aset dan juga pengadaan barang secara online serta keamanan data terjaga, mempermudah dalam mengolah data transaksi dan laporan dapat tersaji dengan cepat dan akurat.
\end{abstract}

Kata Kunci: Inventaris, Pengadaan Barang, Soft System Methodology, Waterfall.

\begin{abstract}
Fast information is needed by every company to help work effectiveness. It has become a necessity for companies to use systems that can produce information quickly. This is what is needed by a company to manage assets and goods in a structured manner so that in the future there will not be a mistake in the recording of the goods even more if it is still done by recording on paper. So we need a way to make an application using the waterfall method, this method aims to develop the system so that it can be done sequentially, then to correct this problem another approach is needed with Soft System Methodology (SSM) to solve problems within the company in order to obtain other goals, until finally be a reference for developing and improving other services by connecting procurement management. With the inventory information system that is integrated with this website-based procurement makes it easy for the general affair to record assets and also procure goods online and maintain data security, making it easier to process transaction data and reports can be presented quickly and accurately.
\end{abstract}

Keywords: Inventaris, Pengadaan Barang, Soft System Methodology, Waterfall. 


\section{PENDAHULUAN}

Perkembangan teknologi di era globalisasi seperti sekarang ini, hampir semua kegiatan manusia tidak lepas dari teknologi informasi yang sudah menjadi suatu kebutuhan. Besarnya kebutuhan manusia akan informasi juga memicu perkembangan komputer sebagai alat bantu untuk mempermudah manusia dalam pengolahan data. Dalam pengembangan ilmu pengetahuan dan perkembangannya pada saat ini menjadikan informasi memiliki peranan yang sangat penting dalam usaha menciptakan kemajuan disemua bidang kehidupan manusia. Dengan adanya teknologi informasi telah banyak dirasakan kemudahan dalam mendapatkan informasi yang cepat, tepat dan akurat.

Adanya sistem informasi sangat membantu dalam pemecahan masalah terutama dalam hal pengolahan data. Penggunaan komputer juga dapat dijadikan alat untuk mencapai tujuan dan mencari kemudahan dalam melakukan suatu proses pekerjaan, terutama yang melibatkan banyak data(Wanti et al., 2020). Hampir di semua instansi-instansi baik yang bersifat negeri maupun swasta menggunakan sistem informasi, bahkan usaha-usaha kecil, menengahpun sudah memanfaatkan keberadaan sistem informasi(Fadlil \& Prawira, 2020).

Inventarisasi barang merupakan pencatatan data yang hubungannya dengan barang atau aset didalam sebuah instansi(Agarwal \& Vijayalakshmi, 2019). Umumnya kegiatan dalam inventarisasi barang adalah pencatatan pengadaan barang, penempatan, mutasi, dan pemeliharaan(Berbasis et al., 2019). Selama ini proses inventarisasi barang di kantor operasional PT Mindreach Consulting masih manual dengan menggunakan buku dan form kertas sebagai media pencatatannya, hal ini dirasakan sangat beresiko untuk beberapa tahun kedepannya karena akan semakin banyak data yang ditulis, sehingga saat ini tidak jarang sering terjadi kesalahan data seperti redundansi (duplikasi data), kehilangan data, ketidakakuratan data bahkan sulit dalam mencari lembaran dokumen data yang terdahulu.
Melihat permasalahan tersebut perlu dicari pemecahan permasalahnya, dimana diperlukan sebuah pendekatan yang dapat menganalisa keadaaan tersebut oleh sebab itu penulis menggunakan pemecahan masalahnya melalui perancangan Soft System Methodology (SSM) hingga memberikan masukkan menjadi sebuah sistem informasi inventaris terintegrasi dengan pengadaan barang yang nantinya akan dibangun pada platform web. Dengan harapan aplikasi tersebut akan memberikan kemudahan-kemudahan dalam memproses data untuk memperoleh informasi yang diinginkan, khususnya dalam hal pengelolaan inventaris barang pada kantor PT Mindreach Consulting.

\section{METODE PENELITIAN}

Penelitian ini dimulai dari metode pengumpulan data yang meliputi studi lapangan yaitu melalui observasi, wawancara, serta kuisioner, dan juga melalui penelitian terdahulu. metode pengembangan sistem menggunakan metode terstruktur yaitu metode waterfall yang memiliki 5 tahap(Press, 1983). Namun pada penelitian ini hanya sampai pada tahap implementation. Dimana pada tahap pertama yaitu planning melakukan perencanaan pengembangan untuk menentukan proses bisnis usulan. Tahap kedua yaitu analysis melakukan analisa menggunakan Soft Systems Methodology (SSM). Tahap berikutnya yaitu design pada tahap ini dilakukan pemodelan sistem menggunakan UML, perancangan database, sampai pada perancangan antarmuka. Tahap keempat yaitu implementation pada tahap ini dilakukan implementasi coding sistem, implementasi database, testing implementasi sistem.

Tahapan proses yang akan dilakukan dalam penelitian ini digambarkan dalam diagram alir pada (Gambar 1) sebagai berikut: 


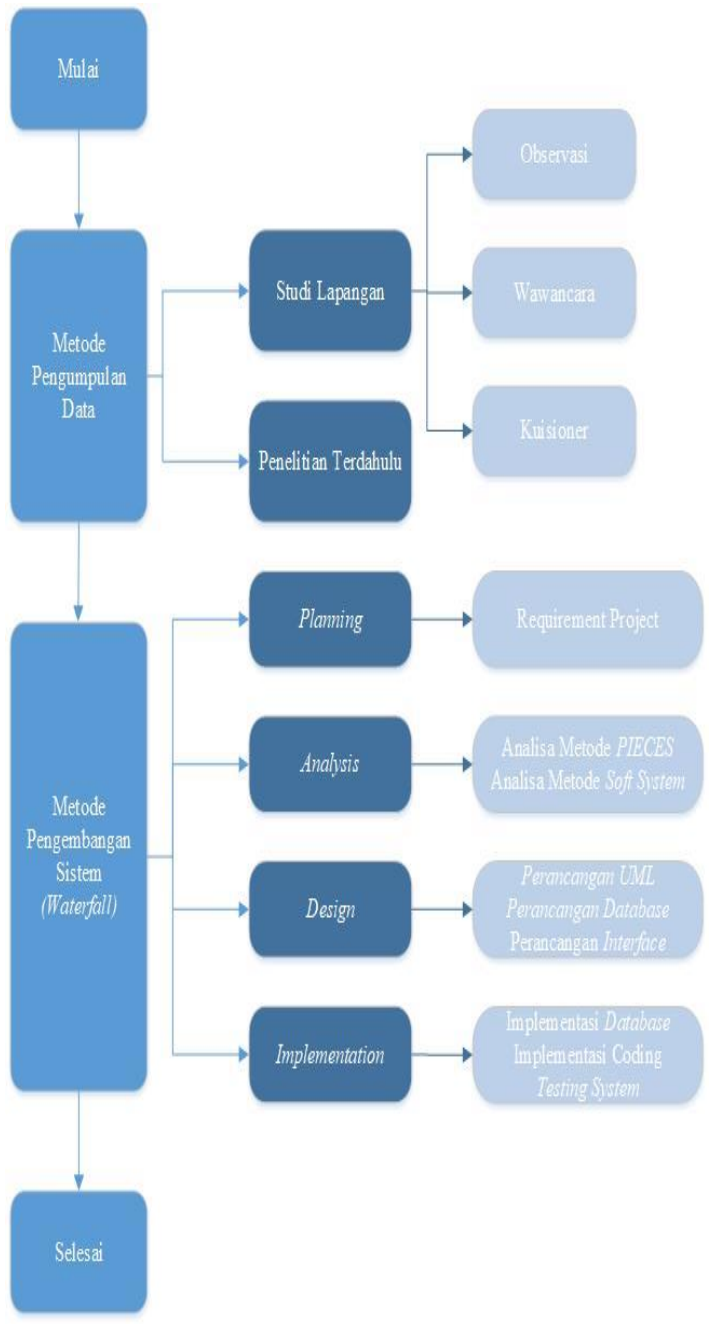

Gambar. 1. Diagram alir penelitian

\section{Analisa Proses Bisnis Usulan}

Tahap ini adalah menganalisa kebutuhan yang diperlukan dalam pembuatan aplikasi inventaris dan procurement untuk PT Mindreach Consulting. Pada tahap ini dianalisa fitur-fitur yang perlu dibangun di dalam Aplikasi Inventaris Integrasi Procurement. Pada tahapan ini dihasilkan sistem usulan dalam bentuk flowchart untuk Aplikasi Inventaris Integrasi Procurement, seperti ditunjukkan oleh (Gambar 2).

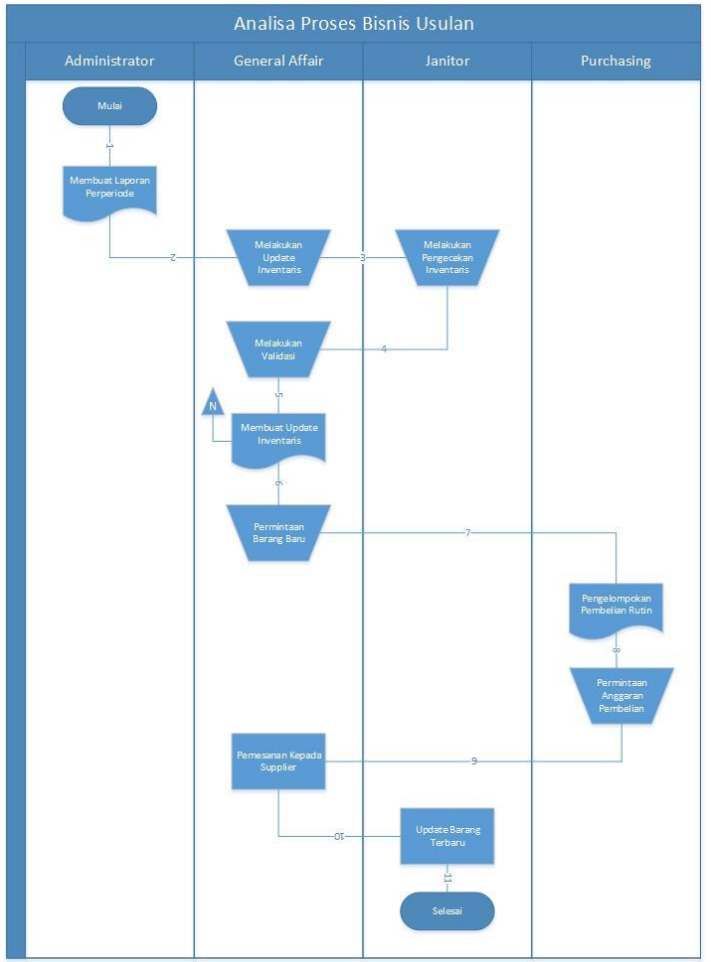

Gambar. 2. Analisa proses bisnis usulan

Keterangan (Gambar 2) Analisa Proses Bisnis Usulan :

1. Administrator membuat laporan secara periode.

2. General Affair melakukan pengecekan tentang kebutuhan tambahan barang inventaris.

3. Janitor melakukan pengecekan barang dilapangan sesuai laporan.

4. General Affair melakukan validasi dari laporan terbaru.

5. General Affair membuat update inventaris barang.

6. General Affair melakukan permintaan barang kepada Purchasing.

7. Purchasing melakukan pengelompokan barang pembelian rutin.

8. Purchasing melakukan untuk permintaan anggaran pembelian barang.

9. General Affair melakukan pemesanan kepada supplier.

10. Janitor melakukan update terbaru jika barang telah ada. 


\section{Soft System Methodology}

Hasil dari studi pengenalan masalah di PT Mindreach Consuling diperoleh melalui proses FGD dan observasi. Metode observasi dilakukan dengan melihat situasi tempat, fasilitas kerja, kegiatan bekerja, dan sarana pendukung dibidang IT dalam PT Mindreach Consuling. Metode FGD digunakan untuk melengkapi observasi dan memperdalam penelitian knowledge sistem informasi management inventaris yang belum terlihat jelas(Studi et al., n.d.). FGD melibatkan Direksi, Manajer, General Affair, Purchasing, dan Janitor. Penggalian informasi dari wawancara diperoleh hasil diantaranya yaitu sistem pencatatan aset dan pengadaan barang.

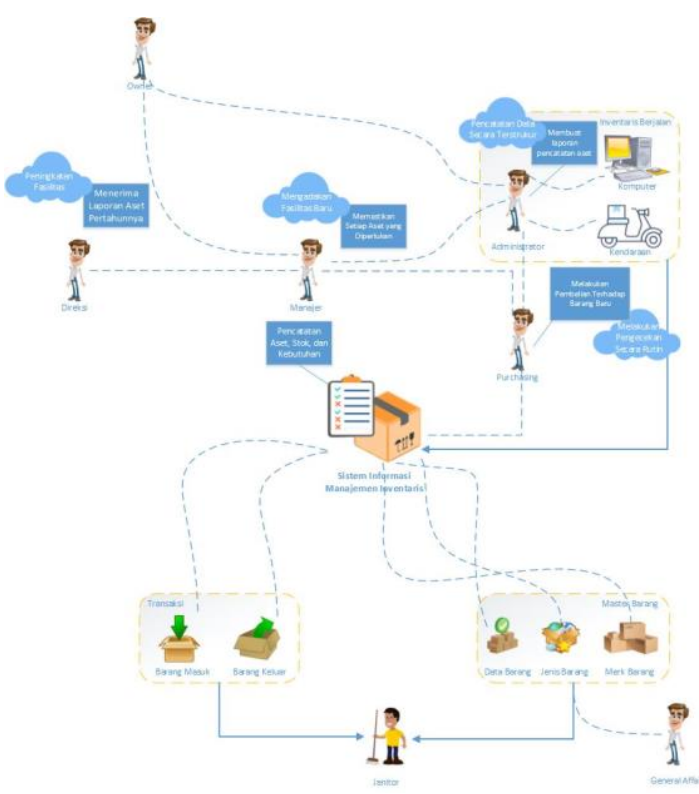

Gambar. 3. Rich-Picture PT Mindreach Consulting

TABEL 1

Keterangan Simbol Rich Picture

\begin{tabular}{|c|c|}
\hline Simbol & Keterangan \\
\hline & $\begin{array}{l}\text { Arah yang menyatakan unsur } \\
\text { regulasi dan informasi. }\end{array}$ \\
\hline \multirow[t]{4}{*}{$---\rightarrow$} & $\begin{array}{l}\text { Garis yang menyatakan elemen } \\
\text { saling terhubung }\end{array}$ \\
\hline & Keadaan yang diketahui oleh pelaku \\
\hline & $\begin{array}{l}\text { Keadaan yang } \\
\begin{array}{l}\text { menggambarkan } \\
\text { kebutuhan pelaku yang belum } \\
\text { terpenuhi. }\end{array}\end{array}$ \\
\hline & Jenis Kegiatan yang dilaksanakan \\
\hline
\end{tabular}

Setelah menggambarkan situasi masalah melalui Rich Picture, langkah selanjutnya dalam penyelesaian suatu masalah menggunakan pendekatan Soft System Methodology (SSM) adalah melakukan identifikasi komponen permasalahan melalui elemen CATWOE. Hasil identifikasi tersebut dapat dilihat pada (Tabel 2).

TABEL 2

Rich-Picture PT MindREACH CONSUlTing

\begin{tabular}{|c|c|c|c|}
\hline No & Element & Definisi & $\begin{array}{c}\text { Hasil } \\
\text { Identifikasi }\end{array}$ \\
\hline 1 & $\begin{array}{l}\text { Customer } \\
\text { (C) }\end{array}$ & $\begin{array}{l}\text { Siapa saja } \\
\text { yang } \\
\text { mendapatk } \\
\text { an manfaat } \\
\text { dari sistem } \\
\text { tersebut }\end{array}$ & $\begin{array}{l}\text { Team general } \\
\text { affair dan juga } \\
\text { bagian } \\
\text { purchasing }\end{array}$ \\
\hline 2 & $\operatorname{Actor}(A)$ & $\begin{array}{l}\text { Siapa saja } \\
\text { yang } \\
\text { melakukan } \\
\text { transformat } \\
\text { ion }\end{array}$ & $\begin{array}{l}\text { Manajemen } \\
\text { dari PT } \\
\text { Mindreach } \\
\text { Consulting } \\
\text { yang ingin } \\
\text { menjadikan } \\
\text { teknologi } \\
\text { dapat berada } \\
\text { didalam } \\
\text { perusahaan, } \\
\text { dan juga divisi } \\
\text { IT }\end{array}$ \\
\hline 3 & $\begin{array}{l}\text { Transforma } \\
\text { tion }(T)\end{array}$ & $\begin{array}{l}\text { Proses } \\
\text { perubahan } \\
\text { dari input } \\
\text { menjadi } \\
\text { output }\end{array}$ & $\begin{array}{l}\text { Cara yang } \\
\text { paling tepat } \\
\text { untuk } \\
\text { memulai } \\
\text { pemindahan } \\
\text { data aset dari } \\
\text { form kertas } \\
\text { menjadi } \\
\text { terkomuputeri } \\
\text { sasi }\end{array}$ \\
\hline 4 & $\begin{array}{l}\text { Worldview } \\
(W)\end{array}$ & $\begin{array}{l}\text { Cara } \\
\text { pandang } \\
\text { yang } \\
\text { membuat } \\
\text { transformat } \\
\text { ion berarti }\end{array}$ & $\begin{array}{l}\text { Kesadaran } \\
\text { akan data } \\
\text { menjadi } \\
\text { menumpuk } \\
\text { pada masa } \\
\text { mendatang } \\
\text { serta resiko } \\
\text { apabila tetap } \\
\text { menggunakan } \\
\text { sistem } \\
\text { pencatatan } \\
\text { dengan kertas } \\
\text { untuk aset } \\
\text { perusahaan }\end{array}$ \\
\hline 5 & Owner $(O)$ & $\begin{array}{l}\text { Siapa saja } \\
\text { yang dapat } \\
\text { mengontrol } \\
\text { sistem }\end{array}$ & $\begin{array}{l}\text { General affair } \\
\text { dan } \\
\text { purchasing }\end{array}$ \\
\hline 6 & $\begin{array}{l}\text { Environme } \\
n t\end{array}$ & $\begin{array}{l}\text { Kendala } \\
\text { apa saja }\end{array}$ & $\begin{array}{l}\text { Minimalnya } \\
\text { pengetahuan }\end{array}$ \\
\hline
\end{tabular}




\begin{tabular}{|l|l|l|l|}
\hline Constraints & yang dapat & IT \\
(E) & menghamb & sebelumnya \\
& at & tentang \\
& pelaksanaa & manajemen \\
& n & aset inventaris \\
& transformat & dengan cara \\
& ion & pencatatan \\
& & barang secara \\
& & terstruktur \\
& & dengan \\
& & komputer \\
\hline
\end{tabular}

\section{Perancanan Sistem}

UML (Unified Modeling Language) adalah standar bahasa yang banyak digunakan di dunia industri untuk mendefinisikan requirement, membuat analis dan desain, serta menggambarkan arsitektur dalam pemrograman berorientasi objek(Benmoussa et al., 2019). Penelitian ini menggunakan diagram use case dalam memanfaatkan UML. Diagram use case berfungsi untuk memodelkan aspek perilaku suatu sistem atau untuk menggambarkan apa saja yang seharusnya dilakukan oleh sistem(Suendri, 2018). Diagram use case dapat dilihat pada (Gambar 4). (Gambar 4) menjelaskan terdapat 4 aktor dan 35 use case yang dimiliki pada penelitian ini.

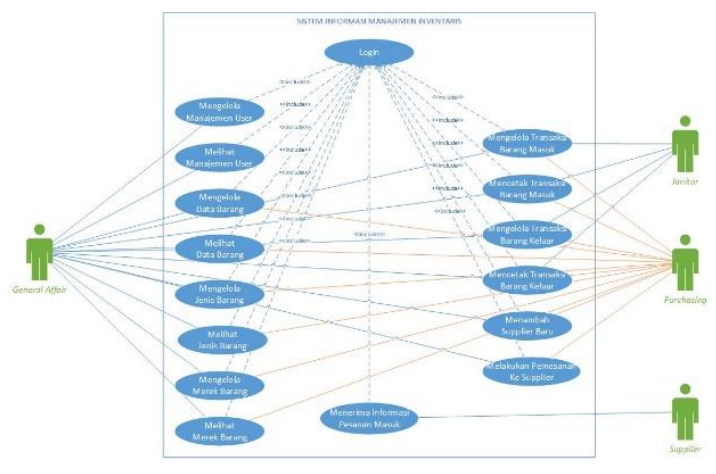

Gambar. 1. Use Case Diagram

Dari use case di atas, diketahui beberapa kebutuhan fungsional sistem. Berikut adalah kebutuhan fungsional sistem yang dimiliki.

1) General Affair Dapat Login

2) General Affair Dapat Mengelola Manajemen User

3) General Affair Dapat Melihat Manajemen User

4) General Affair Dapat Mengelola Data Barang
5) General Affair Dapat Melihat Data Barang

6) General Affair Dapat Mengelola Jenis Barang

7) General Affair Dapat Melihat Jenis Barang

8) General Affair Dapat Mengelola Merek Barang

9) General Affair Dapat Melihat Merek Barang

10) General Affair Dapat Mengelola Transaksi Barang Masuk

11) General Affair Dapat Mencetak Transaksi Barang Masuk

12) General Affair Dapat Mengelola Transaksi Barang Keluar

13) General Affair Dapat Mencetak Transaksi Barang Keluar

14) General Affair Dapat Menambah Suplier Baru

15) General Affair Dapat Melakukan Pemesanan ke Suplier

16) Purchasing Dapat Login

17) Purchasing Dapat Mengelola Data Barang

18) Purchasing Dapat Melihat Data Barang

19) Purchasing Dapat Mengelola Jenis Barang

20) Purchasing Dapat Melihat Jenis Barang

21) Purchasing Dapat Mengelola Merek Barang

22) Purchasing Dapat Melihat Merek Barang

23) Purchasing Dapat Mengelola Transaksi Barang Masuk

24) Purchasing Dapat Mencetak Transaksi Barang Masuk

25) Purchasing Dapat Mengelola Transaksi Barang Keluar

26) Purchasing Dapat Mencetak Transaksi Barang Keluar

27) Purchasing Dapat Menambah Suplier Baru

28) Purchasing Dapat Melakukan Pemesanan ke Suplier

29) Janitor Dapat Login

30) Janitor Dapat Mengelola Transaksi Barang Masuk

31) Janitor Dapat Mencetak Transaksi Barang Masuk 
32) Janitor Dapat Mengelola Transaksi Barang Keluar

33) Janitor Dapat Mencetak Transaksi Barang Keluar

34) Supplier Dapat Login

35) Supplier Dapat Menerima Informasi Pesanan Masuk

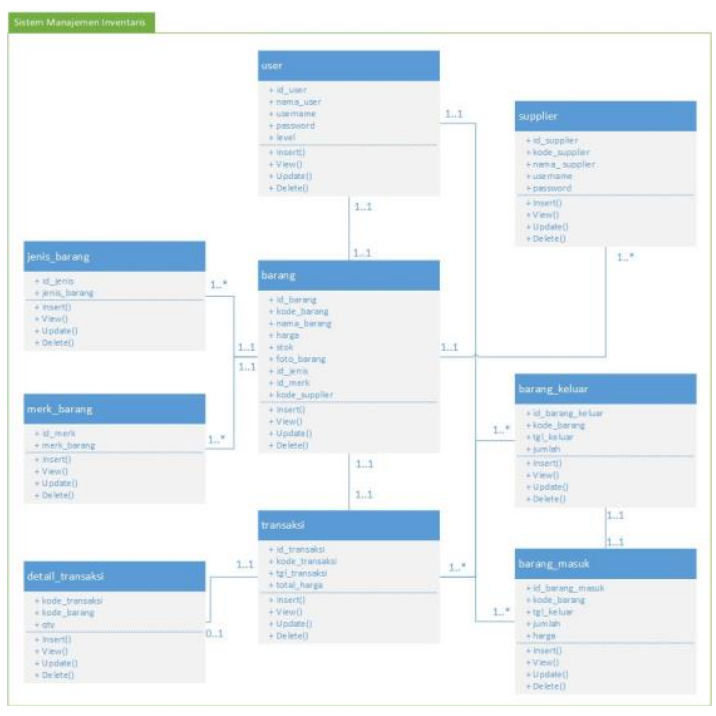

Gambar. 2. Class Diagram

Diagram lain yang digunakan dalam UML adalah class diagram. Class diagram adalah diagram UML yang paling dasar dan banyak digunakan. Ini menunjukkan pandangan statis dari suatu sistem yang terdiri dari kelas, konteksnya (termasuk generalisasi/spesialisasi, asosiasi, agregasi dan komposisi), operasi kelas dan atribut(Press, 1983). Cara class diagram digambar (elemen notasi yang digunakan dan tingkat detailnya) dan bagaimana interpretasinya tergantung pada perspektif. Ada tiga perspektif berbeda yang dapat digunakan saat menggambar class diagram(Sukmawati \& Priyadi, 2019). Class diagram yang dibangun terdapat pada (Gambar 5).

\section{Basis Data}

Basis data yang digunakan dalam penelitian ini adalah MySQL. MySQL merupakan software RDBMS (atau server database) yang dapat mengelola database dengan cepat, dapat menampung data dalam jumlah sangat besar, dapat diakses oleh banyak user (multi user), dan dapat melakukan suatu proses secara sinkron atau berbarengan (multithreaded)(Susanto, 2017)(Arwani, 2020).

\section{Perancangan Antarmuka Sistem}

Rancangan antarmuka sistem dapat dilihat pada (Gambar 6) sampai (Gambar 10) di bawah ini. Terdapat 5 menu utama pada antar muka. Pertama adalah login, kedua dashboard tampilan aplikasi, ketiga data transaksi, keempat form pemesanan supplier, dan kelima adalah tampilan dashboard dari user supplier.

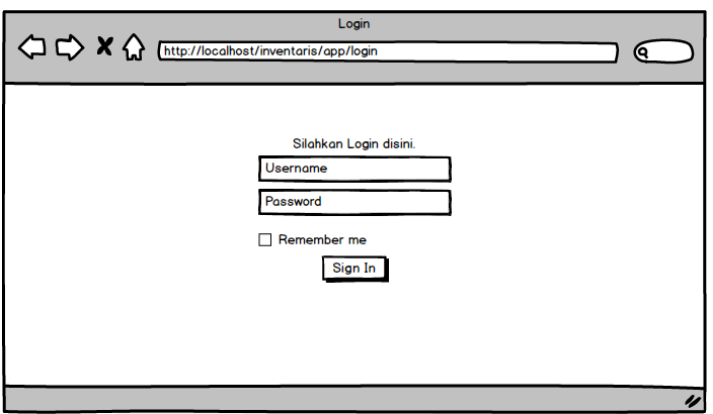

Gambar. 3. Perancangan Antarmuka Login

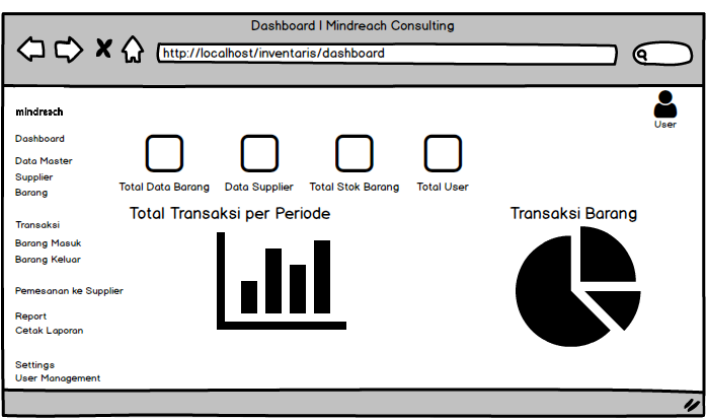

Gambar. 4. Perancangan Antarmuka Dashboard

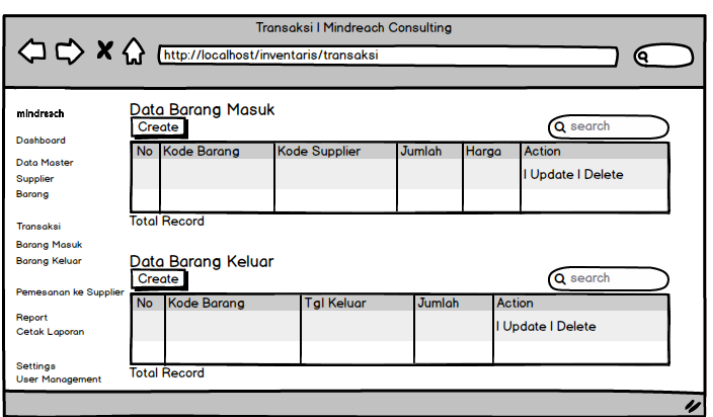

Gambar. 5. Perancangan Antarmuka Data Transaksi 


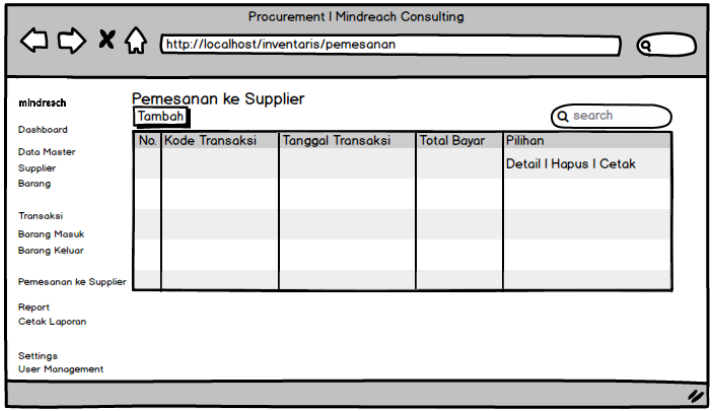

Gambar. 6. Perancangan Antarmuka Pemesanan

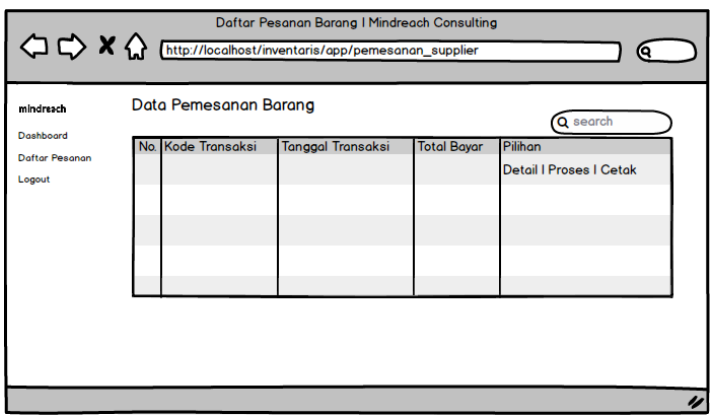

Gambar 7. Perancangan Antarmuka Dashboard Supplier

\section{HASIL DAN PEMBAHASAN}

Hasil dari penelitian ini adalah Aplikasi Inventaris Integrasi Procurement Berbasis Web. (Gambar 11) merupakan form login tampilan awal aplikasi, (Gambar 12) adalah antarmuka halaman dashboard yang akan ditampilkan setelah user sukses melakukan login. Untuk melakukan pendataan data transaksi user dapat melakukan dengan cara masuk menu transaksi sesuai pada (Gambar 13) kemudian pilih data berdasarkan jenisnya (keluar atau masuk), serta untuk melakukan order barang pada supplier yang telah terdaftar, user bisa memilih pada menu Pemesanan ke Supplier seperti yang tertera pada (Gambar 14).

Setelah user general affair atau purchasing selesai melakukan pemesanan dari menu Pemesanan ke Supplier maka data berhasil dikirimkan kepada supplier terkait, aplikasi akan langsung mengirim data pemesanan ke user supplier. Tampilan dashboard pesanan supplier dapat dilihat pada (Gambar 15).

\section{Tampilan Antarmuka}

Berikut adalah implementasi aplikasi sesuai dengan rancangan antar muka yang telah dirancang sebelumnya, antara lain :

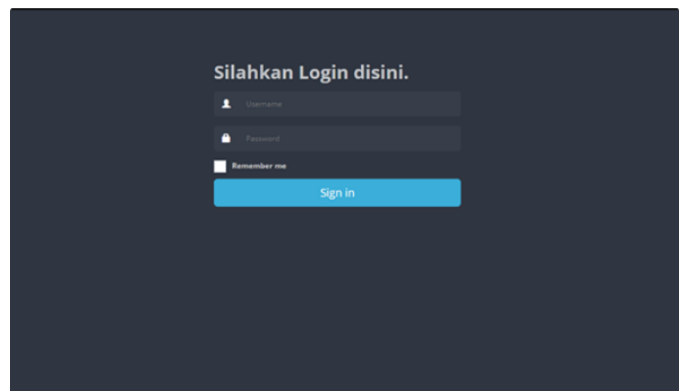

Gambar. 18. Halaman Login
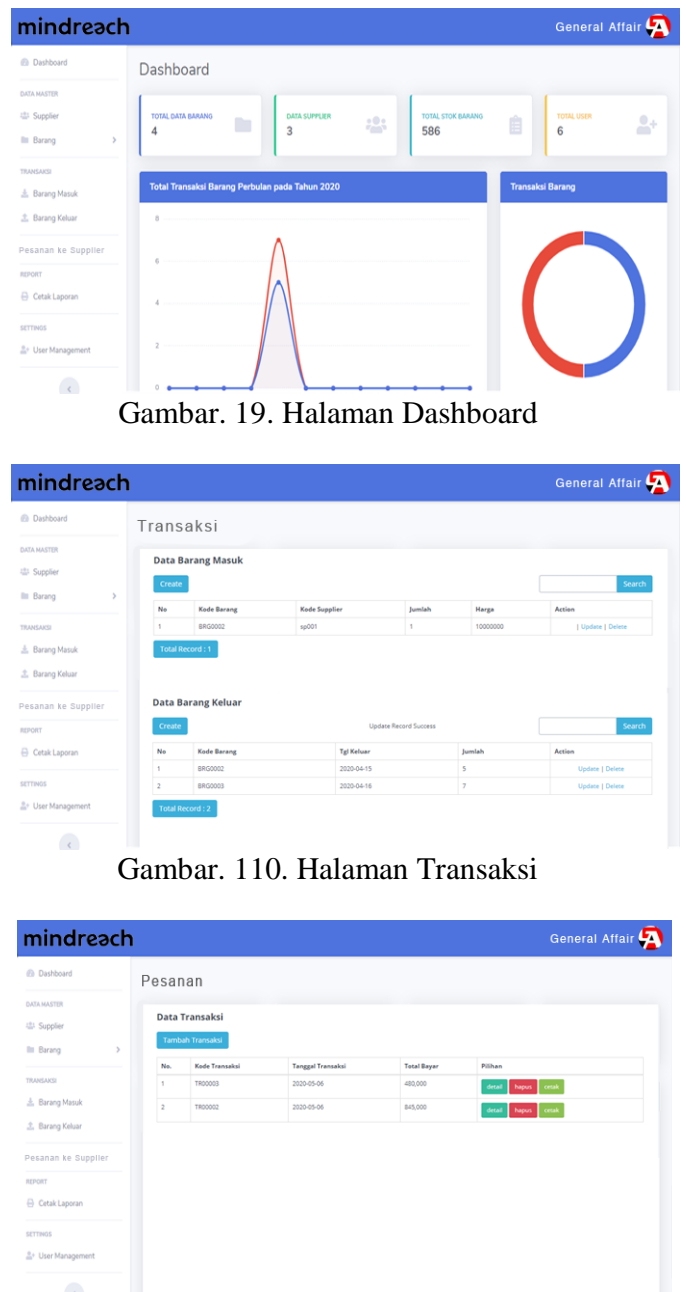

Gambar. 111. Halaman Pesanan ke Supplier

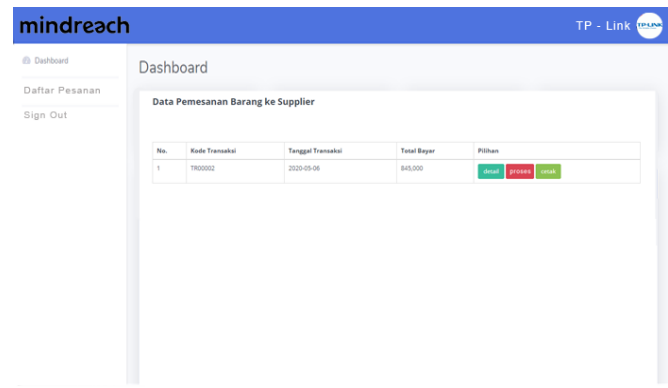

Gambar. 112. Halaman Dashboard Supplier 
TABEL 3

Pengujian PADA Form Login

\begin{tabular}{|c|c|l|l|c|}
\hline No. & Test Case & \multicolumn{1}{|c|}{ Hasil yang Diharapkan } & Hasil Pengujian & $\begin{array}{c}\text { Hasil } \\
\text { Test }\end{array}$ \\
\hline 1 & $\begin{array}{l}\text { Login dengan Hak } \\
\text { Akses General Affair }\end{array}$ & $\begin{array}{l}\text { General Affair memasukkan } \\
\text { username benar dan password } \\
\text { salah. }\end{array}$ & Peringatan Login tidak sesuai & OK \\
\hline & $\begin{array}{l}\text { General Affair memasukkan } \\
\text { username salah dan password } \\
\text { yang salah. }\end{array}$ & Peringatan Login tidak sesuai & OK \\
\hline & $\begin{array}{l}\text { General Affair memasukkan } \\
\text { username benar dan password } \\
\text { benar }\end{array}$ & $\begin{array}{l}\text { Peringatan Login sukses dan } \\
\text { General Affair masuk ke halaman } \\
\text { dashboard. }\end{array}$ & OK \\
\hline
\end{tabular}

TABEL 4

Pengujian Pada Data Transaksi

\begin{tabular}{|c|c|c|c|c|}
\hline No. & Test Case & Hasil yang Diharapkan & Hasil Pengujian & $\begin{array}{c}\text { Hasil } \\
\text { Test }\end{array}$ \\
\hline 1 & Klik Menu Create & $\begin{array}{l}\text { Tampilkan menu untuk } \\
\text { membuat data transaksi baru }\end{array}$ & $\begin{array}{l}\text { Sistem menampilkan form baru } \\
\text { pembuatan data transaksi }\end{array}$ & OK \\
\hline 2 & Klik Menu Search & 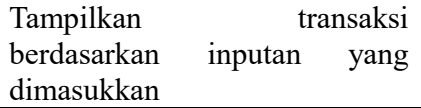 & $\begin{array}{l}\text { Sistem menampilkan hasil } \\
\text { pencarian berdasarkan input }\end{array}$ & OK \\
\hline 3 & Klik Menu Update & $\begin{array}{lcr}\text { Tampikan } & \text { form } & \text { untuk } \\
\text { melakukan } & \text { perubahan } & \text { data } \\
\text { transaksi } & & \end{array}$ & $\begin{array}{l}\text { Sistem menampilkan form } \\
\text { perubahan untuk } \text { update }\end{array}$ & OK \\
\hline 4 & Klik Menu Delete & $\begin{array}{l}\text { Melakukan aksi penghapusan } \\
\text { data }\end{array}$ & $\begin{array}{l}\text { Sistem menampilkan peringatan } \\
\text { penghapusan data }\end{array}$ & OK \\
\hline
\end{tabular}

TABEL 5

Pengujian Pada Pemesanan Ke SupPlier

\begin{tabular}{|l|l|l|l|c|}
\hline No. & \multicolumn{1}{|c|}{ Test Case } & \multicolumn{1}{|c|}{ Hasil yang Diharapkan } & \multicolumn{1}{|c|}{ Hasil Pengujian } & $\begin{array}{c}\text { Hasil } \\
\text { Test }\end{array}$ \\
\hline 1 & $\begin{array}{l}\text { Klik Menu Tambah } \\
\text { Transaksi }\end{array}$ & $\begin{array}{l}\text { Tampilkan form untuk membuat } \\
\text { pesanan baru kepada supplier }\end{array}$ & $\begin{array}{l}\text { Sistem menampilkan form baru } \\
\text { pembuatan pesanan baru }\end{array}$ & OK \\
\hline 2 & Klik Menu Detail & $\begin{array}{l}\text { Tampilkan informasi detail } \\
\text { transaksi yang telah dilakukan }\end{array}$ & $\begin{array}{l}\text { Sistem menampilkan halaman } \\
\text { detail pesanan transaksi }\end{array}$ & OK \\
\hline 3 & Klik Menu Hapus & $\begin{array}{l}\text { Melakukan aksi penghapusan } \\
\text { data }\end{array}$ & $\begin{array}{l}\text { Sistem menampilkan peringatan } \\
\text { penghapusan data }\end{array}$ & OK \\
\hline 4 & Klik Menu Cetak & $\begin{array}{l}\text { Menampilkan data pesanan } \\
\text { untuk dicetak }\end{array}$ & $\begin{array}{l}\text { Sistem menampilkan halaman } \\
\text { pesanan dalam bentuk pdf }\end{array}$ & OK \\
\hline
\end{tabular}

\section{Pengujian}

Pengujian sistem dilakukan dengan melakukan blackbox testing untuk membuktikan bahwa Aplikasi Inventaris Integrasi Procurement dapat berfungsi sesuai tujuannya(Jaya, 2018). Hasil pengujian dapat dilihat pada (Tabel 3) sampai (Tabel 5). Pengujian yang telah dilakukan pada fungsi login, fungsi data transaksi barang keluar dan masuk, serta fungsi proses pemesanan ke supplier menunjukkan kinerja aplikasi yang baik, karena dapat memberikan hasil keluaran seperti yang diharapkan(Cholifah et al., 2018).

Pengujian Aplikasi Inventaris Integrasi
Procurement ini juga dilakukan pada 20 orang responden untuk melihat tingkat kepuasan pengguna aplikasi yang telah di rancang bangun. Pengujian sederhana dengan standar yang bagus, penelitian dianggap berhasil apabila sampel mulai dari 10 hingga 20(Alwi, 2012). Bagian yang diperhitungkan dalam penilaian adalah seberapa menarik penampilan website, kemudahan dalam penggunaan, informasi yang diberikan jelas dan sesuai pilihan dan kegunaan website. Hasil kuesioner di hitung menggunakan penilaian skala Likert seperti pada (Tabel 7). 
TABEL 6

Penilaian SKala LiKerT

\begin{tabular}{|l|l|}
\hline \multicolumn{1}{|c|}{ Nilai } & \multicolumn{1}{c|}{ Keterangan } \\
\hline $0 \%-19,99 \%$ & Sangat Tidak Setuju \\
\hline $20 \%-39,99 \%$ & Tidak Setuju \\
\hline $40 \%-59,99 \%$ & Netral \\
\hline $60 \%-79,99 \%$ & Setuju \\
\hline $80 \%-100 \%$ & Sangat Setuju \\
\hline
\end{tabular}

TABEL 7

Hasil PENGUJian Skala LiKeRT

\begin{tabular}{|c|l|c|c|c|c|c|c|}
\hline No & \multicolumn{1}{|c|}{ Pernyataan } & STS & TS & N & S & SS & Nilai \\
\hline 1 & Penampilan aplikasi menarik & - & - & 4 & 13 & 3 & $79 \%$ \\
\hline 2 & Aplikasi mudah dimengerti & - & - & 2 & 10 & 8 & $86 \%$ \\
\hline 3 & $\begin{array}{l}\text { Aplikasi dapat memberikan informasi yang jelas dan } \\
\text { sesuai pilihan }\end{array}$ & - & - & 3 & 7 & 10 & $87 \%$ \\
\hline 4 & Aplikasi berguna bagi anda & - & - & - & 10 & 10 & $90 \%$ \\
\hline
\end{tabular}

\section{KESIMPULAN}

Aplikasi Inventaris Integrasi Procurement ini dibangun dengan framework codeigniter berbasis web dengan metode pengembangan perangkat lunak waterfall. Data transaksi yang diinputkan pada aplikasi disimpan oleh sistem pada database $M y S q l$ dan dapat mencetak laporan dengan output microsoft excel. Hasil pengujian terhadap fitur-fitur di dalam aplikasi menunjukkan Aplikasi Inventaris Integrasi Procurement dapat berfungsi sesuai tujuannya.

Saran bagi penelitian selanjutnya adalah meningkatkan sistem pencarian suppier dengan cara membuat sebuah fitur tender, sehingga dalam penyempurnaan sistem procurement dapat menjadi lebih optimal dalam mencari supplier untuk memenuhi kebutuhan perusahaan dalam pengadaan barang.

\section{DAFTAR PUSTAKA}

Agarwal, V., \& Vijayalakshmi, A. (2019). Recommender system for surplus stock clearance. International Journal of Electrical and Computer Engineering, 9(5), 3813-3821.

Alwi, I. (2012). Kriteria Empirik Dalam Menentukan Ukuran Sampel. Formatif: Jurnal Ilmiah Pendidikan MIPA.

Arwani, I. (2020). Optimasi Proses Klasterisasi Di Mysql Dbms Dengan
Mengintegrasikan Algoritme MicKmeans Menggunakan Bahasa Optimization of the Clasterization Process in Mysql Dbms By Integrating Mic-Kmeans Algorithm Using Sql Language in Stored. 7(2).

Benmoussa, K., Laaziri, M., Khoulji, S., Larbi, K. M., \& Yamami, A. El. (2019). A new model for the selection of web development frameworks: application to PHP frameworks. International Journal of Electrical and Computer Engineering (IJECE), 9(1), 695.

Berbasis, R., Ward, M., Studi, P., \& Pt, K. (2019). Kajian Perencanaan Strategis Sistem Informasi Pada Bisnis a Study of Strategic Planning Information System in Retail Bussiness Based on Ward \& Peppard Methodology: Case Study Pt . Gramedia Asri. 6(3).

Cholifah, W. N., Yulianingsih, Y., \& Sagita, S. M. (2018). Pengujian Black Box Testing pada Aplikasi Action \& Strategy Berbasis Android dengan Teknologi Phonegap. STRING (Satuan Tulisan Riset Dan Inovasi Teknologi), 3(2), 206.

Fadlil, A., \& Prawira, T. Y. (2020). Market Basket Analysis to Identify Stock Handling Patterns and Item Arrangement Patterns Using Apriori Algorithms. 6(1), 33-41.

Jaya, T. S. (2018). Pengujian Aplikasi dengan 
Metode Blackbox Testing Boundary Value Analysis (Studi Kasus: Kantor Digital Politeknik Negeri Lampung). Jurnal Informatika Pengembangan IT (JPIT), 3(2), 45-46.

Press, P. (1983). Recent advances in nonlinear computational mechanics. Advances in Engineering Software (1978), 5(3), 171.

Studi, P., Industri, T., Buana, U. M., Teknologi, D., \& Pertanian, I. (n.d.). Soft system methodology. IX(1), 1-9.

Suendri. (2018). Implementasi Diagram UML (Unified Modelling Language) Pada Perancangan Sistem Informasi Remunerasi Dosen Dengan Database Oracle (Studi Kasus: UIN Sumatera Utara Medan). Jurnal Ilmu Komputer Dan Informatika, 3(1), 1-9.

Sukmawati, R., \& Priyadi, Y. (2019).
Perancangan Proses Bisnis Menggunakan UML Berdasarkan Fit/Gap Analysis Pada Modul Inventory Odoo. INTENSIF: Jurnal Ilmiah Penelitian Dan Penerapan Teknologi Sistem Informasi, 3(2), 104.

Susanto, S. (2017). Implementasi Keamanan Data Menggunakan Algoritma Rivest Code 4 (RC4) Pada Sistem Informasi Inventory Stock Barang Pada Distributor PT.Wings Food. Lontar Komputer: Jurnal Ilmiah Teknologi Informasi, 8(2), 77.

Wanti, L. P., Maharrani, R. H., Wachid, N., \& Prasetya, A. (2020). Optimation economic order quantity method for a support system reorder point stock. 10(5), 4992-5000. 